\title{
Ultrasensitive determination of lead and chromium contamination in well and dam water based on fluorescence quenching of CdS quantum dots
}

\author{
Jafar Abolhasani · Javad Hassanzadeh • \\ Elnaz Seyed Jalali
}

Received: 25 April 2014/ Accepted: 21 August 2014/Published online: 7 October 2014

(C) The Author(s) 2014. This article is published with open access at Springerlink.com

\begin{abstract}
We report lead $\left(\mathrm{Pb}^{2+}\right)$ and chromium $\left(\mathrm{Cr}^{3+}\right)$ determination in several water samples obtained from Nahand dam, Karkaj and Azarshahr well, tab and mineral waters to study their contamination in these systems. Determination method is based on the characteristic aggregation and fluorescence quenching of synthesized CdS quantum dots (QDs) at $555 \mathrm{~nm}$ by considered cations. Water-soluble and biocompatible CdS QDs modified with thioglycolic acid have been synthesized in one step and characterized by fluorescence and absorption spectroscopy. The fluorescence intensity of CdS QDs is linearly proportional to $\mathrm{Pb}^{2+}$ and $\mathrm{Cr}^{3+}$ concentration from 0.8 to 100 and 3 to $400 \mathrm{ng} \mathrm{mL}^{-1}$ with a detection limit of 0.3 and $1.2 \mathrm{ng} \mathrm{mL}^{-1}$, respectively. Other potentially interfering ions such as iron, sodium, potassium, calcium, and magnesium ions did not affect the luminescence. The method showed lower detection blank and higher sensitivity.
\end{abstract}

Keywords Lead - Chromium - Contamination · Fluorescence quenching $\cdot$ CdS quantum dots

\section{Introduction}

Pollution by heavy metal ions, particularly lead $\left(\mathrm{Pb}^{2+}\right)$ and chromium $\left(\mathrm{Cr}^{3+}\right)$, causes a serious hazard to human life and the environment. $\mathrm{Pb}^{2+}$, the heaviest stable element, is one of the four metals that have the greatest effects on human health. Due to its characteristics as a very toxic

J. Abolhasani $(\bowtie) \cdot$ J. Hassanzadeh · E. S. Jalali

Department of Chemistry, College of Science, Tabriz Branch,

Islamic Azad University, Tabriz, Iran

e-mail: abolhasani@iaut.ac.ir poison to humans, even at low concentrations, $\mathrm{Pb}^{2+}$ has been studied extensively. Many diseases are spread because of the toxic effects of $\mathrm{Pb}^{2+}$, such as respiratory diseases like asthma and allergies, lowered IQ and other nervous system disorders, impaired biosynthesis of hemoglobin and anemia, high blood pressure, kidney damage and brain [1]. The use of $\mathrm{Pb}^{2+}$ in electronics has been restricted by European Parliament to reduce unsafe chemical waste leakage to the groundwater [2]. Also Environmental Protection Agency (EPA) set the allowed limit of $\mathrm{Pb}^{2+}$ in drinking water as $15 \mathrm{ng} \mathrm{mL}^{-1}$. Unfortunately, $\mathrm{Pb}^{2+}$ is still used in refineries to increase gasoline octane number. Cigarette smoke has also a small amount of $\mathrm{Pb}^{2+}$. Also, $\mathrm{Pb}^{2+}$ enters drinking water and soil due to corrosion of water lead pipes.

Non-degradable and bio-fermentation $\mathrm{Cr}^{3+}$ in nature as well as its extensive usage is the main reason that it is considered a serious environmental pollutant. $\mathrm{Cr}^{3+}$ is one of the main pollutants in water, because of its lower storage requirements in some industrial activities. Chromium is known to be toxic to plants and animals because of its potentially carcinogenic effect duo to permeability of cell membranes.

Therefore, due to health concerns and legal restrictions, rapid and sensitive methods are critical for evaluation of heavy metals. Several methods have been reported for $\mathrm{Pb}^{2+}$ and $\mathrm{Cr}^{3+}$ determination based on electrothermal atomic absorption spectrometry [3, 4], X-ray fluorescence [5], chromatography [6], electrochemical methods [7-9], mass spectroscopy $[10,11]$ and photometric methods [12]. These methods often require complex and expensive equipment, skilled labor, and high time for preparation of samples. Also, it is necessary to further improve their sensitivity and selectivity. In the meantime, fluorescence recently has attracted much attention, because of its high sensitivity. 
Several fluorescent probes based on organic luminescent dyes [13-16] have been reported for detection of $\mathrm{Pb}^{2+}$ or $\mathrm{Cr}^{3+}$. These methods generally displayed relatively high detection limits. In contrast, quantum dots (QDs) displayed superior luminescence properties and stability in aqueous solutions [17, 18]. There are several reports for ion detection based on the fluorescence intensity of quantum dots. Since, Chen and Rosenzweig showed that fluorescence intensity of thioglycerol-coated $\mathrm{CdS}$ QDs was reduced selectively in the presence of $\mathrm{Cu}^{2+}$ [19], several research groups have applied different types of quantum dots as luminescence probe for $\mathrm{Hg}^{2+}$ [20-24], $\mathrm{Cu}^{2+}$ [2529], $\mathrm{Ag}^{+}[25,30], \mathrm{Pb}^{2+}$ [31-33] based on their fluorescence quenching effect. All the reports show the interaction between the analyte and quantum dots which change their physical and photochemical features.

This paper describes a sensitive method for the determination of $\mathrm{Pb}^{2+}$ and $\mathrm{Cr}^{3+}$ contaminations in several environmental water samples, based on fluorescence quenching of thioglycolic acid (TGA) capped cadmium sulfide (CdS) quantum dots (QDs). The quenched intensity of fluorescence was proportional to the concentration of $\mathrm{Pb}^{2+}$ and $\mathrm{Cr}^{3+}$ in different conditions. The procedure is simple, convenient and sensitive with a detection limit of 0.3 and $1.2 \mathrm{ng} \mathrm{mL}^{-1}$ for $\mathrm{Pb}^{2+}$ and $\mathrm{Cr}^{3+}$, respectively. It does not need any pretreatments for samples. The proposed method was successfully applied to the determination of $\mathrm{Pb}^{2+}$ and $\mathrm{Cr}^{3+}$ in real samples including Nahand dam, Karkaj and Azarshahr well, tab and mineral waters.

\section{Experimental}

\section{Apparatus}

Fluorescence measurements were performed on a RF-5301 spectrofluorophotometer (Shimadzu, Japan) equipped with a xenon lamp source, using $1.0 \mathrm{~cm}$ quartz cell with a cell holder kept in a constant-temperature water circulating device, thermo bath TB-85. The widths of both excitation and emission slits were set at $5 \mathrm{~nm}$. The optimum excitation and emission wavelengths for CdS QDs were found to be 427 and $555 \mathrm{~nm}$, respectively. Absorption spectra were recorded by a UV-1800 spectrophotometer (Shimadzu, Japan).

\section{Materials}

All experiments were carried out with analytical grade chemicals and solvents. Doubly distilled deionized water was used for the preparation of all solutions. Cadmium chloride $\left(\mathrm{CdCl}_{2} \cdot 5 \mathrm{H}_{2} \mathrm{O}\right)$, sodium sulfide $\left(\mathrm{Na}_{2} \mathrm{~S} \cdot 9 \mathrm{H}_{2} \mathrm{O}\right)$ and thioglycolic acid (TGA) were all purchased from sigma Aldrich and were used without further purification. Buffer solutions of acetate and phosphate $\left(0.5 \mathrm{~mol} \mathrm{~L}^{-1}\right)$ were prepared by dissolving the appropriate amount of sodium acetate (Merck) or $\mathrm{NaH}_{2} \mathrm{PO}_{4} \cdot 2 \mathrm{H}_{2} \mathrm{O}$ (Merck) in double distilled water, respectively. The $\mathrm{pHs}$ of these buffer was adjusted to 5 and 6 , respectively. Stock standard solutions of $100 \mathrm{mg} \mathrm{L}^{-1} \mathrm{~Pb}^{2+}$ and $\mathrm{Cr}^{3+}$ were prepared in water from lead nitrate (Merck) and chromium (III) nitrate (Merck), respectively.

\section{Synthesis of TGA-capped CdS quantum dots}

TGA-capped CdS QDs were synthesized in aqueous solution using a simple reported procedure [28]. Briefly, $100 \mathrm{ml}$ of TGA $\left(0.05 \mathrm{~mol} \mathrm{~L}^{-1}\right)$ solution and $100 \mathrm{ml}$ of $\mathrm{CdCl}_{2}$ $\left(0.02 \mathrm{~mol} \mathrm{~L}^{-1}\right)$ solution were mixed in a round bottom flask. The $\mathrm{pH}$ of this solution was adjusted in 8 by $\mathrm{NaOH}$ $\left(1 \mathrm{~mol} \mathrm{~L}^{-1}\right)$ solution. White residue, appear in the solution, was dissolved by adding $\mathrm{NaOH}$ solution and finally, the clear solution was obtained. This was probably due to formation of Cd-thioglycolic complexes with different structures at different $\mathrm{pH}$ values because of different dissociation of Carboxylate and sulfhydryl group. The reaction mixture was then heated up to $90{ }^{\circ} \mathrm{C}$ in the argon atmosphere. Then $50 \mathrm{ml}$ of $\mathrm{Na}_{2} \mathrm{~S}\left(0.02 \mathrm{~mol} \mathrm{~L}^{-1}\right)$ was added. After refluxing for $2 \mathrm{~min}$, the flask was submerged in the ice-water bath until it cooled to room temperature. After purification, QDs were used as fluorescent nanoparticles.

\section{General procedure}

For $\mathrm{Pb}^{2+}$ determination, $75 \mu \mathrm{L}$ synthesized QDs solution and $200 \mu \mathrm{L}$ phosphate buffer $(\mathrm{pH}=5)$ were transferred to $5 \mathrm{~mL}$ volumetric flask. Then an appropriate volume of sample or standard $\mathrm{Pb}^{2+}$ solution was added and the final volume was made to $5 \mathrm{~mL}$ with distilled water. The fluorescence intensity of the solution was recorded as analytical signal.

For $\mathrm{Cr}^{3+}$ determination, $100 \mu \mathrm{L}$ synthesized QDs solution and $200 \mu \mathrm{L}$ acetate buffer $(\mathrm{pH}=5)$ were transferred to $5 \mathrm{~mL}$ volumetric flask. Then an appropriate volume of sample or standard $\mathrm{Cr}^{3+}$ solution was added and the final volume was made to $5 \mathrm{~mL}$ with distilled water. The fluorescence intensity of the solution was recorded as analytical signal.

\section{Results and discussion}

Characterization of thioglycolic acid-capped CdS quantum dots

Synthesized thioglycolic acid-capped CdS QDs (TGAcapped CdS QDs) are optically characterized by UV-vis absorption spectroscopy and fluorometry. The TGA-capped CdS QDs show long emission wavelengths and a high 
Fig. 1 a Absorption, b Fluorescence spectra and c TEM image of synthesized aqueous TGA-capped CdS QDs
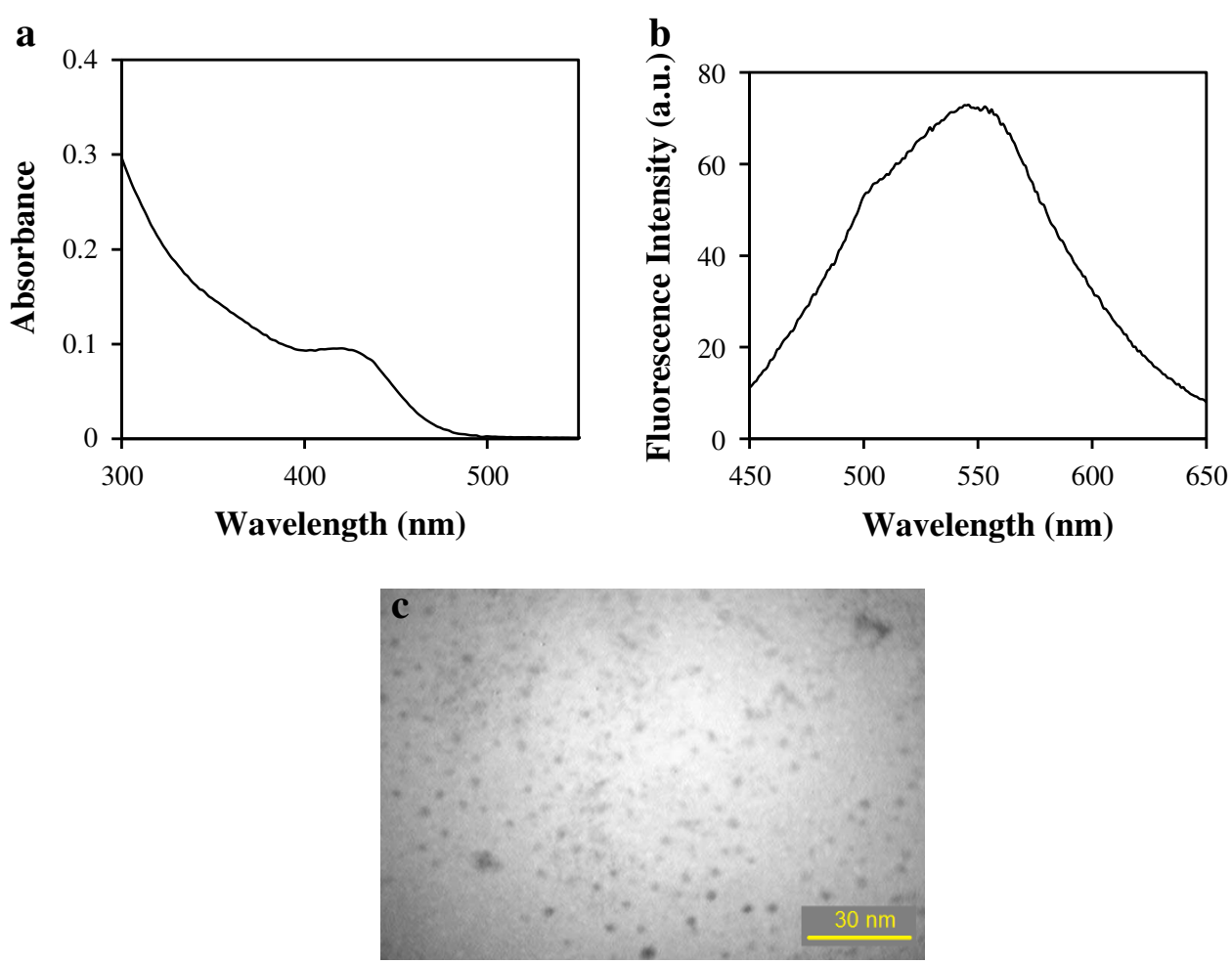

Fig. 2 Fluorescence spectra of aqueous TGA-capped CdS QDs in the presence of different concentrations of $\mathbf{a ~} \mathrm{Cr}^{3+}$ and b $\mathrm{Pb}^{2+}$. a QDs $75 \mu \mathrm{L}$, phosphate buffer $0.01 \mathrm{M}$, $\mathrm{pH}=6(1-7: 0,25,50,100$, 200, 300, $\left.400 \mathrm{ng} \mathrm{mL}^{-1}\right)$. b QDs $100 \mu \mathrm{L}$, acetate buffer $0.01 \mathrm{M}$, $\mathrm{pH}=5(1-7: 0,1,2.5,5,10$, $\left.50,75 \mathrm{ng} \mathrm{mL}^{-1}\right)$

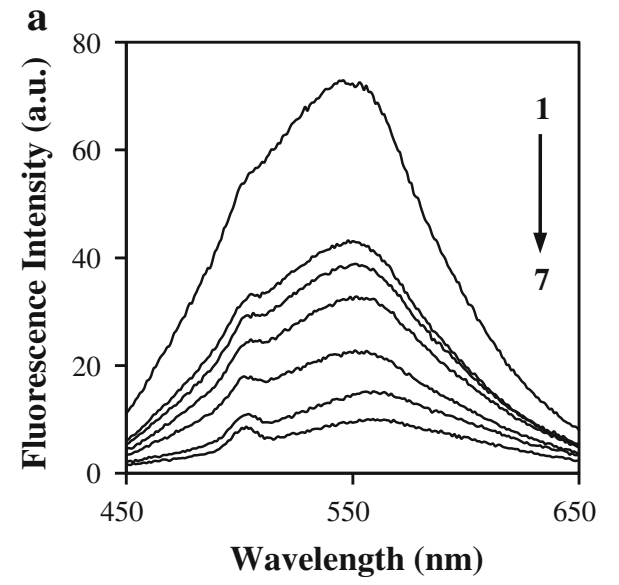

separation between the excitation and emission wavelengths (ca. $125 \mathrm{~nm}$ ) simplifying fluorescence measurements. The absorption spectrum shows well-defined excitonic absorption peak at wavelength of $427 \mathrm{~nm}$, and a sharp band edge emission peak $(\lambda=555 \mathrm{~nm})$, which was independent of the excitation wavelength, was obtained in the FL spectrum (Fig. 1).

Also TEM (transmission electron microscopy) image of Synthesized QDs is shown in Fig. 1c.

Effect of cations on the fluorescence of QDs

The fluorescence intensity $\left(\lambda_{\mathrm{ex}}=427 \mathrm{~nm}\right)$ of quantum dots drastically decreases with some cations in a certain condition. It is observed that synthesized QDs have high tendency for $\mathrm{Pb}^{2+}$ and $\mathrm{Cr}^{3+}$. The more the $\mathrm{Pb}^{2+}$ or $\mathrm{Cr}^{+3}$ concentration, the lower was the FL intensity obtained. This decrease was proportional to each cation concentration (Fig. 2).

\section{Optimization of condition}

It is clear that $\mathrm{pH}$ influences the fluorescence intensity of the complex significantly. To investigate the effects of $\mathrm{pH}$ on determinations, the $\mathrm{pH}$ ranges between 4 and 9 . At lower $\mathrm{pHs}$, there is no fluorescence intensity because of the protonation of the thiol groups and aggregation of the QDs [35]. The maximum value of $F_{0} / F$ was obtained when $\mathrm{pH}$ 
Fig. 3 Effects of $\mathrm{pH}$ on the (QDs $=100 \mu \mathrm{L}$, phosphate buffer $0.05 \mathrm{M}$ ) and $\mathbf{b} \mathrm{Pb}^{2+}$ $5 \mathrm{ng} \mathrm{mL}^{-1}(\mathrm{QDs}=75 \mu \mathrm{L}$, acetate buffer $0.05 \mathrm{M}$ ) $F_{0} / F$ for a $\mathrm{Cr}^{3+} 10 \mathrm{ng} \mathrm{mL}^{-1}$
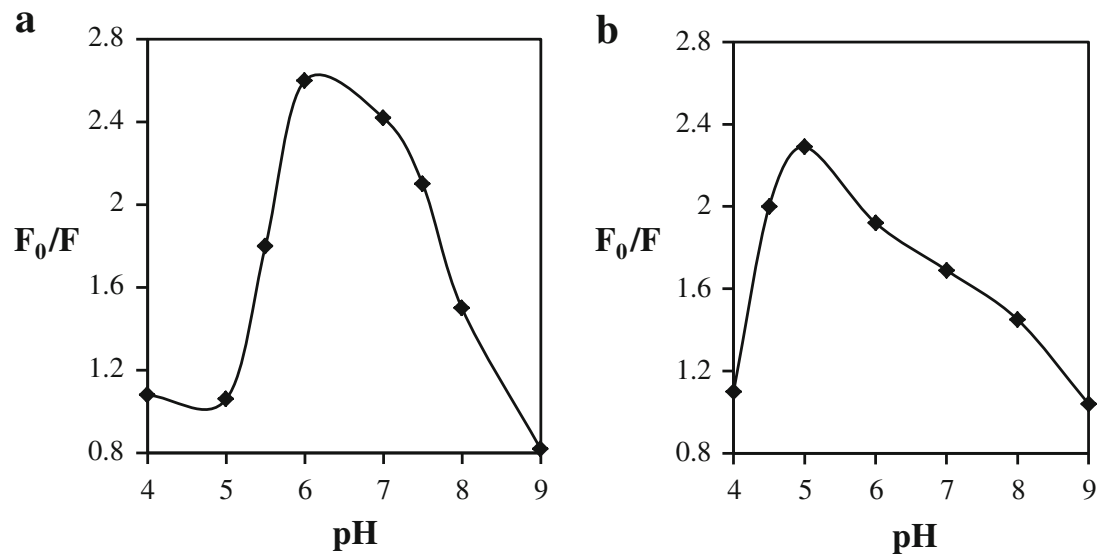

Fig. 4 Effects of QDs amount on the $F_{0} / F$ for $\mathbf{a ~ C r}^{3+}$

$10 \mathrm{ng} \mathrm{mL}^{-1}$ (phosphate buffer $0.05 \mathrm{M}, \mathrm{pH}=6$ ) and $\mathbf{b} \mathrm{Pb}^{2+}$ $5 \mathrm{ng} \mathrm{mL}^{-1}$ (acetate buffer $0.05 \mathrm{M}, \mathrm{pH}=5$ )
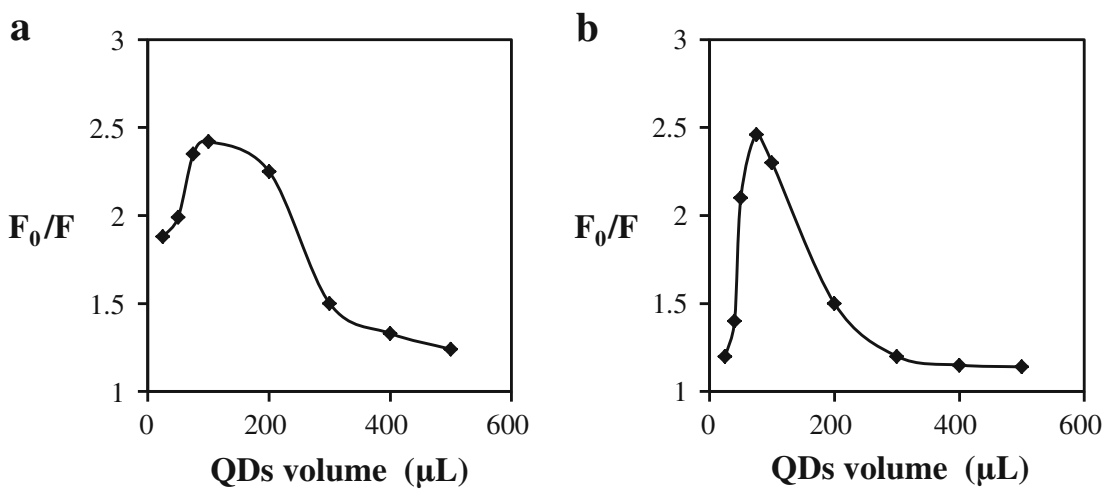

was 6 and 5 for $\mathrm{Cr}^{3+}$ and $\mathrm{Pb}^{2+}$, respectively (Fig. 3). $\left(F_{0}\right.$ and $F$ are the fluorescence intensity of the aqueous $\mathrm{CdS}$ QDs without and at a given analyte concentration). Therefore, these optimal $\mathrm{pH}$ values were chosen to be applied in further experiments.

It was found that the concentration of QDs affected not only the fluorescent intensity but also the sensitivity of the assay. As shown in Fig. 4, high concentration of aqueous QDs decreases the sensitivity and causes self-quenching of the QDs fluorescence. Also, very low concentration of QDs gives very weak fluorescence intensity, which may result in narrow linear range. Thus, 100 and $75 \mu \mathrm{L}$ of QDs was chosen for $\mathrm{Cr}^{3+}$ and $\mathrm{Pb}^{2+}$ determinations, respectively. In selected optimal values of the quantum dots, wide linear range and low detection limit concentrations are achieved.

The effect of buffer solution on fluorescence intensity system was discussed. To do so, different buffer solutions such as phosphate, tris and acetate were investigated. The results showed that phosphate and acetate have the greatest effect on the fluorescence quenching of TGA-capped CdS QDs in the presence of $\mathrm{Cr}^{3+}$ and $\mathrm{Pb}^{2+}$, respectively. Hence, these buffers were selected in all experiments. Optimization of buffer concentration was carried out and the result is showed in Fig. 5. Maximum signal was obtained in $0.01 \mathrm{M}$ for both states.
In results, the best optimal conditions for the measurement of $\mathrm{Cr}^{3+}$ are: QDs $=100 \mu \mathrm{L}$, phosphate buffer $0.01 \mathrm{M}, \mathrm{pH}=6$, and for $\mathrm{Pb}^{2+}$ are: $\mathrm{QDs}=75 \mu \mathrm{L}$, acetate buffer $0.01 \mathrm{M}, \mathrm{pH}=5$.

\section{Quantitative characteristics}

Under optimal condition, the ratio of FL intensity $\left(F_{0} / F\right)$ in the absence $\left(F_{0}\right)$ and presence of analyte $(F)$ was plotted versus the concentration of each analyte in $\mathrm{ng} \mathrm{mL} L^{-1}$. Calibration graphs and corresponding FL spectra are shown in Fig. 6. Obtained analytical characteristics are indicated in Table 1.

The quenching ability of $\mathrm{Cr}^{3+}$ and $\mathrm{Pb}^{2+}$ can be expressed by Stern-Vollmer equation:

$\frac{F_{0}}{F}=1+K_{\mathrm{SV}}[C]$

where $F$ and $F_{0}$ are fluorescence quantum yield or fluorescence intensity of quantum dots with $(F)$ and without $\left(F_{0}\right)$ extinguishing or analyte. $K_{\mathrm{sv}}$ is the Stern-Vollmer constant. Linear equations between concentration and relative fluorescence intensity obtained for $\mathrm{Cr}^{3+}$ and $\mathrm{Pb}^{2+}$ $(y=0.0024 x+1.065$ and $y=0.0098 x+1.057$, respectively) are consistent with Stern-Vollmer equation. 
Fig. 5 Effects of buffer concentration on the $F_{0} / F$ for a $\mathrm{Cr}^{3+} 10 \mathrm{ng} \mathrm{mL}^{-1}$

$(\mathrm{QDs}=100 \mu \mathrm{L}$, phosphate buffer $\mathrm{pH}=6$ ) and $\mathbf{b} \mathrm{Pb}^{2+}$ $5 \mathrm{ng} \mathrm{mL}^{-1}$ (QDs $=75 \mu \mathrm{L}$, acetate buffer $\mathrm{pH}=5$ )

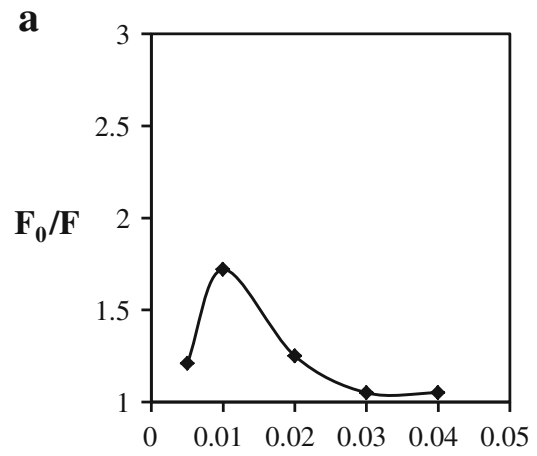

Buffer Concentration (M)

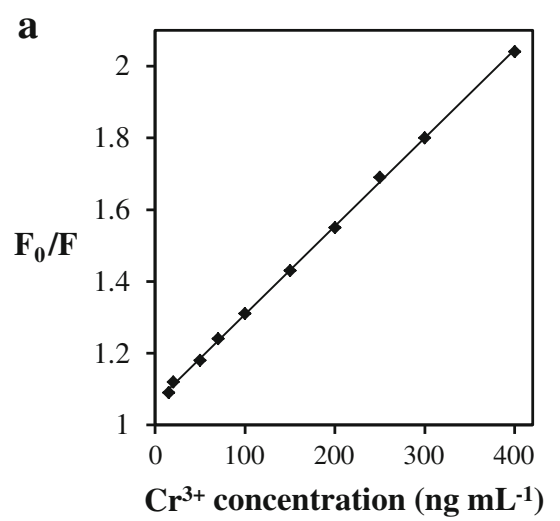

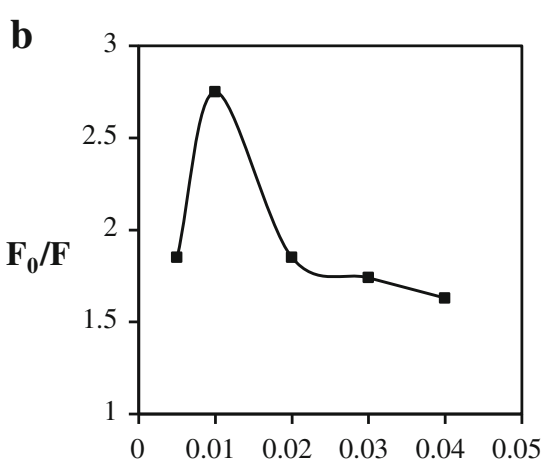

Buffer Concentration (M)

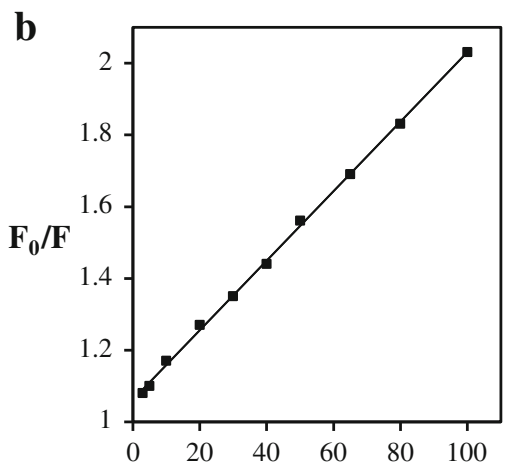

$\mathbf{P b}^{2+}$ concentration (ng $\mathbf{~ m L}^{-1}$ )
Fig. 6 Calibration curve of the a $\mathrm{Cr}^{3+}$ and $\mathbf{b} \mathrm{Pb}^{2+}$ in optimum condition
Table 1 Analytical characteristics of the method for the determination of $\mathrm{Cr}^{3+}$ and $\mathrm{Pb}^{2+}$

\begin{tabular}{lll}
\hline Parameter & $\mathrm{Cr}^{3+}$ & $\mathrm{Pb}^{2+}$ \\
\hline Linear range $\left(\mathrm{ng} \mathrm{mL}^{-1}\right)$ & $3-400$ & $0.8-100$ \\
Slope & 0.0024 & 0.0098 \\
Intercept & 1.065 & 1.057 \\
Correlation coefficient $(r)$ & 0.9993 & 0.9979 \\
Number of points & 10 & 10 \\
LOD $(\mathrm{ng} \mathrm{mL}-1)$ & 1.2 & 0.8 \\
$\operatorname{RSD} \%(n=5)$ & $3.2\left(8 \mathrm{ng} \mathrm{mL}^{-1}\right)$ & $2.1\left(5 \mathrm{ng} \mathrm{mL}^{-1}\right)$ \\
$\operatorname{RSD} \%(n=5)$ & $3.0\left(50 \mathrm{ng} \mathrm{mL}^{-1}\right)$ & $3.9\left(10 \mathrm{ng} \mathrm{mL}^{-1}\right)$ \\
$\operatorname{RSD} \%(n=5)$ & $1.4\left(300 \mathrm{ng} \mathrm{mL}^{-1}\right)$ & $2.4\left(50 \mathrm{ng} \mathrm{mL}^{-1}\right)$ \\
\hline
\end{tabular}

Interference of coexisting foreign substances

In order to investigate the effect of coexisting substances on $\mathrm{Cr}^{3+}$ and $\mathrm{Pb}^{2+}$ determination in real samples, various concentrations of interfering ions are added to determination solution ( $1 \mu \mathrm{g} \mathrm{mL}^{-1}$ analyte) and, $F / F_{0}$ value is measured versus interference ion concentration. Interference limit is considered $5 \%$ deviation from the initial $F / F_{0}$ value (Table 2). The results show that the method for analysis of $\mathrm{Cr}^{3+}$ and $\mathrm{Pb}^{2+}$ is free from any interference.
Table 2 Interfering effects of some coexisting ions on $\mathrm{Cr}^{3+}$ and $\mathrm{Pb}^{2+}$ determination

\begin{tabular}{lcc}
\hline Coexisting ions & $\begin{array}{l}\text { Interference } \\
\text { ratio for } \mathrm{Cr}^{3+}\end{array}$ & $\begin{array}{l}\text { Interference } \\
\text { ratio for } \mathrm{Pb}^{2+}\end{array}$ \\
\hline $\mathrm{Hg}^{2+}, \mathrm{Fe}^{3+}$ & 800 & 800 \\
$\mathrm{Cd}^{2+}$ & 300 & 300 \\
$\mathrm{Zn}^{2+}$ & 500 & 300 \\
$\mathrm{Na}^{+}$ & 2,000 & 2,000 \\
$\mathrm{Co}^{2+}$ & 150 & 150 \\
$\mathrm{Cu}^{2+}$ & 200 & 250 \\
$\mathrm{Li}^{+}, \mathrm{Ni}^{2+}, \mathrm{K}^{+}, \mathrm{NO}_{3}{ }^{-}$ & 500 & 500 \\
$\mathrm{CO}_{3}^{2-}$ & 5,000 & 4,000 \\
$\mathrm{SO}_{4}^{2-}$ & 4,000 & 400 \\
$\mathrm{Cl}^{-}$ & 7,000 & 600 \\
\hline
\end{tabular}

Analysis of real samples

The represented method was successfully applied to the quantitative determination of $\mathrm{Cr}^{3+}$ and $\mathrm{Pb}^{2+}$ in the real samples of various compositions such as Nahand dam, Karkaj and Azarshahr well, tab and mineral waters. The real samples were spiked with standard solution of each analyte, and then were analyzed by standard addition 
Table 3 Results for the determination of $\mathrm{Pb}^{2+}$ in the real samples
${ }^{\text {a }}$ Mean of three determinations \pm standard deviation

Table 4 Results for the determination of $\mathrm{Cr}^{3+}$ in the real samples
${ }^{a}$ Mean of three determinations \pm standard deviation

\begin{tabular}{lrlll}
\hline Sample $\left(\mathrm{Pb}^{2+}\right)$ & Add $\left(\mathrm{ng} \mathrm{mL}^{-1}\right)$ & $\begin{array}{l}\text { Found } \\
\text { purposed method }\end{array}$ & Recovery $\%$ & $\begin{array}{l}\text { Found }^{\mathrm{a}}\left(\mathrm{ng} \mathrm{mL}^{-1}\right) \\
\text { standard method }\end{array}$ \\
\hline Karkaj well water & 0 & $4.22 \pm 0.2$ & - & $4.51 \pm 0.3$ \\
& 5 & $9.28 \pm 0.1$ & $101 \pm 2.0$ & - \\
Nahand dam water & 10 & $14.40 \pm 0.3$ & $102 \pm 2.9$ & - \\
& 0 & 0 & - & Not detect \\
Azarshahr well water & 5 & $4.85 \pm 0.11$ & $97.2 \pm 2.2$ & - \\
& 0 & $10.38 \pm 0.21$ & $104 \pm 2.3$ & - \\
& 5 & Not detect & - & Not detect \\
Mineral water & 10 & $5.12 \pm 0.1$ & $102 \pm 2.1$ & - \\
& 0 & $10.14 \pm 0.2$ & $101 \pm 1.9$ & - \\
Tabriz tab water & 5 & Not detect & - & Not detect \\
& 0 & $5.21 \pm 0.1$ & $104 \pm 1.8$ & - \\
& 5 & $10.38 \pm 0.3$ & $104 \pm 2.9$ & - \\
& 10 & Not detect & - & Not detect \\
& $5.11 \pm 0.1$ & $102 \pm 1.7$ & - \\
& & $10.09 \pm 0.3$ & $101 \pm 2.5$ & - \\
\hline
\end{tabular}

\begin{tabular}{lrlll}
\hline Sample $\left(\mathrm{Cr}^{3+}\right)$ & Add $\left(\mathrm{ng} \mathrm{mL}^{-1}\right)$ & $\begin{array}{l}\text { Found } \\
\text { purposed method }\end{array}$ & Recovery \% & $\begin{array}{l}\text { Found }^{\mathrm{a}}\left(\mathrm{ng} \mathrm{mL}^{-1}\right) \\
\text { standard method }\end{array}$ \\
\hline Karkaj well water & 0 & $5.81 \pm 0.12$ & - & $5.48 \pm 0.31$ \\
& 5 & $10.72 \pm 0.18$ & $97.2 \pm 3.6$ & - \\
Nahand dam water & 10 & $15.58 \pm 0.25$ & $97.7 \pm 2.4$ & - \\
& 0 & $12.50 \pm 0.20$ & - & $4.51 \pm 0.14$ \\
Azarshahr well water & 5 & $17.70 \pm 0.15$ & $104 \pm 2.8$ & - \\
& 10 & $22.29 \pm 0.32$ & $97.9 \pm 3.3$ & - \\
& 5 & $9.16 \pm 0.11$ & - & $4.51 \pm 0.22$ \\
Mineral water & 10 & $14.37 \pm 0.15$ & $104 \pm 3.1$ & - \\
& 0 & $19.00 \pm 0.30$ & $98.4 \pm 3.2$ & - \\
Tabriz tab water & 5 & Not detect & - & Not detect \\
& 10 & $5.13 \pm 0.14$ & $103 \pm 2.8$ & - \\
& 0 & $10.05 \pm 0.12$ & $101 \pm 1.1$ & - \\
& 5 & Not detect & - & Not detect \\
& 10 & $4.88 \pm 0.19$ & $97.6 \pm 3.7$ & - \\
& & $9.72 \pm 0.30$ & $97.2 \pm 2.9$ & -
\end{tabular}

method. In Tables 3 and 4, the obtained recovery values in real samples are listed.

The recoveries were between 97 and $104 \%$, showing that the proposed procedure is applicable to the determination of $\mathrm{Cr}^{3+}$ and $\mathrm{Pb}^{2+}$ in environmental samples.

On the other hand, the results were compared with those obtained by a standard method using electrothermal atomic absorption spectroscopy. Statistical analysis using Student $t$ test showed that there are no significant differences between the results of two methods.

\section{Conclusion}

A simple, sensitive and rapid method for determination of $\mathrm{Cr}^{3+}$ and $\mathrm{Pb}^{2+}$ contamination has been offered based on the quenching of the fluorescence of TGA-capped CdS quantum dots. The preparation of quantum dots is very simple, fast and economical. Also the method does not need any pretreatment steps in analysis. The procedure possesses the advantage of wide dynamic range, selectivity and high sensitivity (expressed by the detection limits) 
which may be an incentive to other workers to consider it for determination of $\mathrm{Cr}^{3+}$ and $\mathrm{Pb}^{2+}$ in traces. Finally, this procedure was successfully applied to determine $\mathrm{Cr}^{3+}$ and $\mathrm{Pb}^{2+}$ in environmental real samples.

Acknowledgments This work was supported by Islamic Azad University, Tabriz Branch, Tabriz, Iran.

Open Access This article is distributed under the terms of the Creative Commons Attribution License which permits any use, distribution, and reproduction in any medium, provided the original author(s) and the source are credited.

\section{References}

1. Landrigan, P.J., Todd, A.C.: Lead poisoning. West. J. Med. 161, 153-159 (1994)

2. Directive 2002/95/EC: Restriction of the use of certain hazardous substances in electrical and electronic equipment. European Parliament and Council (2003)

3. Sadeghi, S., Mogaddam, A.Z.: Preconcentration and speciation of trace amount of chromium in saline samples using temperaturecontrolled microextraction based on ionic liquid as extraction solvent and determination by electrothermal atomic absorption spectrometry. Talanta 99, 758-766 (2012)

4. Sardans, J., Montes, F., Penuelas, J.: Determination of As, Cd, $\mathrm{Cu}, \mathrm{Hg}$ and $\mathrm{Pb}$ in biological samples by modern electrothermal atomic absorption spectrometry. Spectrochim. Acta B 65, 97-112 (2010)

5. Orescanin, V., Mikelic, L., Lulic, S., Rubcic, M.: Determination of $\mathrm{Cr}(\mathrm{III})$ and $\mathrm{Cr}(\mathrm{VI})$ in industrial and environmental liquid samples by ED-XRF method. Anal. Chim. Acta 527, 125-129 (2004)

6. Threeprom, J., Purachaka, S., Potipan, L.: Simultaneus determination of $\mathrm{Cr}$ (III)-EDTA and $\mathrm{Cr}(\mathrm{VI})$ by ion interaction chromatography using a $\mathrm{C}_{18}$ column. J. Chromatogr. A 1073, 291-295 (2005)

7. Dominguez, O., Arcos, M.J.: Simultaneus determination of chromium(VI) and chromium(III) at trace levels by adsorptive stripping voltammetry. Anal. Chim. Acta 470, 241-252 (2002)

8. Li, J.J., Zhang, C., Wei, H., Wang, E.K.: Combining chemical reduction with an electrochemical technique for the simultaneous detection of $\mathrm{Cr}(\mathrm{VI}), \mathrm{Pb}(\mathrm{II})$ and $\mathrm{Cd}(\mathrm{II})$. Analyst. 134, 273-277 (2009)

9. Yasri, N.G., Halabi, A.J., Istamboulie, G., Noguer, T.: Chronoamperometric determination of lead ions using PEDOT: PSS modified carbon electrodes. Talanta 85, 2528-2533 (2011)

10. Milne, A., Landing, W., Bizimis, M., Morton, P.: Determination of $\mathrm{Mn}, \mathrm{Fe} \mathrm{Co}, \mathrm{Ni}, \mathrm{Cu}, \mathrm{Zn}, \mathrm{Cd}$ and $\mathrm{Pb}$ in seawater using high resolution magnetic sector inductively coupled mass spectrometry (HR-ICP-MS). Anal. Chim. Acta 665, 200-207 (2010)

11. Beceiro-Gonzalez, E., Guimaraes, A., Alpendurada, M.F.: Optimisation of a headspace-solid-phase micro-extraction method for simultaneous determination of organometallic compounds of mercury, lead and tin in water by gas chromatography-tandem mass spectrometry. J. Chromatogr. A 1216, 5563-5569 (2009)

12. Chai, F., Wang, C.A., Wang, T.T., Li, L., Su, Z.M.: Colorimetric detection of $\mathrm{Pb}^{2+}$ using glutathione functionalized gold nanoparticles. Appl. Mater. Interfaces 2, 1466-1470 (2010)
13. Hosseini, M.S., Belador, F.: Cr(III)/Cr(VI) speciation determination of chromium in water samples by luminescence quenching of quercetin. J. Hazard. Mater. 165, 1062-1067 (2009)

14. Kwon, J.Y., Jang, Y.J., Lee, Y.J.: A highly selective fluorescent chemosensor for $\mathrm{Pb}^{2+}$. J. Am. Chem. Soc. 127, 10107-10111 (2005)

15. Chen, C.T., Huang, W.P.: A highly selective fluoroscent chemosensor for lead ions. J. Am. Chem. Soc. 124, 6246-6247 (2002)

16. Bozkurt, S.S., Ayata, S., Kaynak, I.: Fluorescence-based sensor for $\mathrm{Pb}$ (II) using tetra-(3-bromo-4-hydroxyphenyl) porphyrin in liquid and immobilized medium. Spectrochim. Acta A 72, 880-883 (2009)

17. Michalet, X., Pinaud, F.F., Bentolila, L.A., Tsay, J.M., Doose, S., Li, J.J., Sundaresan, G., Wu, A.M., Gambhir, S.S., Weiss, S.: Quantum dots for live cells, in vivo imaging, and diagnostics. Science 307, 538-544 (2005)

18. Alivisatos, P.: The use of nanocrystals in biological detection. Nat. Biotechnol. 22, 47-52 (2004)

19. Chen, Y., Rosenzweig, Z.: Luminescent CdS quantum dots as selective ion probes. Anal. Chem. 74, 5132-5138 (2002)

20. Xia, Y.S., Zhu, C.Q.: Use of surface-modified CdTe quantum dots as fluorescent probes in sensing mercury (II). Talanta $\mathbf{7 5}$, 215-221 (2008)

21. Cai, Z.X., Yang, H., Zhang, Y., Yan, X.P.: Preparation, characterisation and evaluation of water-soluble L-cysteine capped $\mathrm{CdS}$ nanoparticles as fluorescence probe for detection of $\mathrm{Hg}(\mathrm{II})$ in aqueous solution. Anal. Chim. Acta 559, 234-239 (2006)

22. Li, H., Zhang, Y., Wang, X., Gao, Z.: A luminescent nanosensor for $\mathrm{Hg}(\mathrm{II})$ based on functionalised $\mathrm{CdSe} / \mathrm{ZnS}$ quantum dots. Microchim. Acta 160, 119-123 (2008)

23. Chen, J., Gao, Y.C.: A novel fluorescent array for mercury (II) ion in aqueous solution with functionalized cadmium selenide nanoclusters. Anal. Chim. Acta 577, 77-84 (2006)

24. Koneswaran, M., Narayanaswamy, R.: Mercaptoacetic acid capped CdS quantum dots as fluorescence single shot probe for mercury(II). Sens. Actuators. B 139, 91-96 (2009)

25. Gattas-Asfura, KM., Leblanc, RM.: Peptide-coated CdS quantum dots for the optical detection of copper (II) and silver (I) Chem. Commun. 2684-2685 (2003)

26. Fernandez-Arguelles, M.T., Jin, W.J., Costa-Fernandez, J.M., Pereiro, R., Sanz-Medel, A.: Surface-modified CdSe quantum dots for the sensitive and selective determination of $\mathrm{Cu}(\mathrm{II})$ in aqueous solutions by luminescent measurements. Anal. Chim. Acta 549, 20-25 (2005)

27. Xie, H.Y., Liang, J.G.: Luminescent CdSe- ZnS quantum dots as selective $\mathrm{Cu} 2$ + probe. Spectrochim. Acta A 60, 2527-2530 (2004)

28. Zhang, Y., Zhang, H.: L-Cysteine-coated CdSe/CdS core-shell quantum dots as selective fluorescence probe for copper(II) determination. Microchem. J. 89, 142-147 (2008)

29. Koneswaran, M., Narayanaswamy, R.: L-Cysteine-capped ZnS quantum dots based fluorescence sensor for $\mathrm{Cu}^{2+}$ ion. Sens. Actuators B 139, 104-109 (2009)

30. Chen, J.L., Zhu, C.Q.: Functionalised cadmium sulfide quantum dots as fluorescence probe for silver ion determination. Anal. Chim. Acta 546, 147-153 (2005)

31. Ali, E.M., Zheng, Y., Yu, H., Ying, J.Y.: Ultrasensitive $\mathrm{Pb}^{2+}$ detection by glutathione capped quantum dots. Anal. Chem. 79, 9452-9458 (2007)

32. Wu, H., Liang, J., Han, H.: A novel method for the determination of $\mathrm{Pb}^{2+}$ based on the quenching of the fluorescence of CdTe quantum dots. Microchim. Acta 161, 81-86 (2008)

33. Cai, Z., Shi, B., Zhao, L., Ma, M.: Ultrasensitive and rapid lead sensing in water based on environmental friendly and high 
luminescent L-glutathione-capped-ZnSe quantum dots. Spectrochim. Acta A 97, 909-914 (2012)

34. Winter, J.O., Gomez, N., Gatzert, S., Schmidt, C.E., Korgel,

B.A.: Variation of cadmium sulfide nanoparticle size and photoluminescence intensity with altered aqueous synthesis conditions. Colloid. Surf. A 254, 147-157 (2005)
35. Wang, G.L., Dong, Y.M., Yang, H.X., Li, Z.J.: Ultrasensitive cysteine sensing using citrate-capped $\mathrm{CdS}$ quantum dots. Talanta 83, 943-947 (2011) 